\title{
Between Security and Liberalization: Decoding Turkey's Struggle with the PKK
}

\author{
ERSEL AYDINLI* \\ Department of International Relations, Bilkent University, and \\ Center for Eurasian Strategic Studies (ASAM), Ankara, Turkey
}

\begin{abstract}
This article identifies the dynamics of the national security syndrome and the pendulum swing between security and liberalization that are embedded in the Turkish political system. It then explores how these are reflected in the problematic and conflictual processes of Turkish policy formulation with regard to the Kurdistan Workers Party (PKK) in the post-violence era. The article presents evidence of a new impasse surrounding Turkey's southeast/Kurdish question. While Turkey is having difficulties in designing post-terror policies, the PKK appears unprepared to fully disarm and give up. The only route remaining seems to be one of political struggle. After identifying Turkey's structural limits to addressing the issue, the article discusses the implications of these on the future of the conflict, on Turkey's foreign relations with the West, and on the increasingly torn domestic political situation.
\end{abstract}

\section{Introduction}

$\mathrm{A}$ LTHOUGH THE COMBAT STRATEGIES of organized armies have usually failed against ethnic insurgencies, Turkey has emerged from a 15-year struggle against the Kurdish PKK movement with a decisive military victory. Turkish security forces have succeeded in eliminating most of the PKK's armed combatants and capturing the group's leader, Abdullah Ocalan, leading to the retreat of virtually all remaining PKK units from Turkish soil. Nevertheless, there are strong indications that a new, political struggle between Turkey and the PKK, in its own way as intensive as the first, has only just begun. Even though this new phase is more political in nature, the primacy of security and threat perceptions seems to be continuing unabated, and the Turkish security establishment seems reluctant to relinquish management of the issue to the political circles.

Several questions persist therefore: Does the military defeat mean that the Kurdish issue will now play a less pivotal role within Turkey's foreign policy, 
and will this allow Turkey to resume previous, more accommodating relations with its Middle Eastern neighbors? Does the PKK's defeat make it easier for Turkey to meet the requirements for European Union accession? Has it proven possible to overcome an ethnic insurgency movement with a military victory? Can the military-led decisiveness of the Turkish political system and the overwhelmingly united national consensus during the military struggle continue to prevail in the era of political struggle? Though the Turkish army won the armed struggle, is it appropriate for the military to be fighting the political one? The answers to these questions seem to be largely 'no', the reasons for which are likely hidden in the historical foundations of the Turkish state structure, which was shaped between conflicting forces of political liberalization and security. The modern manifestation of this problematic can be traced in the emerging patterns of the conflict between Turkey and the various forms of political representation of Kurdish ethnic awareness.

It has been argued that, throughout much of the history of the republic, one of the major domestic Turkish policies has been the containment of any potential political and cultural Kurdish movement. ${ }^{1}$ What the literature has neglected to identify is whether this policy has been a product of political calculation or whether it represents a structural tendency of the Turkish political system. ${ }^{2}$ This article first identifies the dynamics of a national security syndrome that is embedded in the Turkish political system and then explores how this syndrome is reflected in the formulation of Turkish policies towards the Kurdish issue in the post-terror era.

\section{Defining the Liberalization-Security Pendulum}

Certain characteristics of Turkish history and politics long ago created an imbalanced pendulum between political liberalization and security needs. Liberalization attempts in Ottoman-Turkish history rarely took place in a vacuum, and the limiting borders for these attempts were largely determined by the overarching systemic primacy of internal and external security concerns. Several characteristics both emerged from and contributed to the persistence of this structural phenomenon. First, at a time of constant territorial contraction during the Ottoman era, pro-reform circles justified their political liberalization demands as being better able to protect the state/nation from external and internal threats. Security was the end, while political liberalization was seen as the means - an understanding that provides evidence of the longstanding supremacy of security and stability demands. ${ }^{3}$ Second, there was a fear among the elite of uncontrolled power decentralization and its dangerous security implications. This worry was further provoked by a mistrust of ordinary citizens, whom they feared might be empowered by any political reform. ${ }^{4}$ 
Third, the ruling elite that assumed the mission of promoting liberalizing reforms was ironically at the same time the group whose primary responsibility was to protect the country's national security. ${ }^{5}$ At times of immediate threat, when the two identities clashed, the elite's role as the professional security guards of the state and the regime would prevail, automatically spelling an end to liberal policies.

On the other hand, later in the Republican era, once the homeland was liberated and the ruling elite felt that they had guaranteed the more dominant side of the pendulum swing, namely, the security of the regime and the country, they themselves initiated further liberalization attempts. These now sparked true tests for the dilemma between liberalization and security.

The first political liberalization attempt came in 1924 with the formation of the first opposition party, the Progressive and Republican Party (Terakkiperver Cumhuriyet Firkasi). When the subsequent Kurdish-led Sheik Said Rebellion broke out in Turkey's southeast, the existing government's policies towards the rebellion were found by Ataturk and his friends to be overly soft. ${ }^{6}$ Tougher policies were prescribed, and more hawkish figures to conduct them were sought. The initiation of emergency laws and tribunals in a highly securitized environment ${ }^{7}$ cost the life of the new party and put an end to this first attempt at multi-party politics.

The second multi-party attempt, beginning with the founding of the Free Party (Serbest Firka) in 1930, also fell victim to concerns over regime and state security. The ensuing massive societal support for the new party made it clear that potential anti-regime elements were both plentiful and ready to take advantage of multi-party politics in their struggle against the state. The ruling elite's fears of anarchy seemed to be materializing. Ataturk himself, despite the fact that he had initiated this liberalization attempt, was forced to subscribe to the insecurity concerns, saying in a talk with an opposition party leader, 'anarchy, there is anarchy everywhere. You [the opposition party leaders] are oblivious or blind to this fact ... I can't be impartial under these circumstances. ${ }^{8}$ The new party was compelled to close itself down. A subsequent tragic incident, a religious rebellion referred to as the 'Menemen Case', ${ }^{9}$ in which an army officer was beheaded, sealed the final justification in the elite's minds for the primacy of national security. To the elite, any form of power relocation or diffusion to societal elements was determined to be fatal to the state and the regime owing to the fragmented nature of the society. These liberalization failures consolidated a clear national security syndrome among the Turkish elite, which would play as the primary structural criterion for any type of future political liberalization attempt in Turkish domestic politics.

This national security syndrome may explain why Turkey continues to have a difficult time in designing a post-terror political strategy towards the Kurdish issue and the PKK. Replacing their guns with rhetoric, the two sides now appear more like chess players than fighting enemies in Turkey's southeast 
mountains. Ocalan and the PKK may be attempting with their calls for a democratic solution to turn military defeat into political victory, but Turkey seems to be preparing a full-fledged effort to halt any international political recognition - often referred to in Turkey as 'politicization' - of the PKK and the Kurdish issues. In other words, while Ocalan and the PKK attempt to dictate the terms of reform using the threat of terror, ${ }^{10}$ Turkey seems to be adopting strategies to first eliminate the remaining terror threat and then proceed with democratization on its own terms. Turkey faces, however, a dilemma of transforming its current combat psychology while designing the post-terror strategy required for future admittance to the EU.

\section{Turkey's Emerging Response}

Ocalan's proposal of a so-called 'democratic solution' had successfully put the ball in Turkey's court at the start. With the exhilarating atmosphere of possible European Union membership and the concomitant emphasis on the democratization process, Turkish Foreign Minister Ismail Cem spoke positively about the prospect of introducing Kurdish television. Mehmet Ali Irtemcelik, then minister in charge of human rights, organized meetings with NGOs dominated by pro-Kurdish activists, and the influential Turkish Industrialists and Businessmen's Association (TUSIAD) commissioned a report which recommended culture- and language-based reforms. Nevertheless, a more cautious, wait-and-see attitude prevailed in the public sector.

Neither Ocalan's capture nor the proposals in his 'democratic union manifesto' generated a unified response from the Turkish state security establishment, indicating that it had not yet finalized a post-conflict policy towards the PKK. This is not surprising, since Turkey had been primarily geared toward fighting the PKK on the battlefield. With the PKK's shifting of emphasis toward politics, however, there was likely concern that an early response would have been interpreted as dignifying the PKK's new positioning.

An unwelcome response, from Turkey's standpoint, came from Europe, which made it clear that reforms on the Kurdish issue were essential before Turkey could become a European Union member. Visits to southeastern Turkey by European Union and EU member-state government officials boomed in early 2000, with some three hundred reported meetings taking place with Kurdish figures in the region, primarily members of Halkin Demokrasi Partisi (HADEP), Turkey's only Kurdish-oriented political party. ${ }^{11}$ These meetings should not have been unexpected, since reforming the Kurdish issue would very soon be one of the backbones of Turkey's route to joining Europe. Gunther Verheugen, the European Commissioner responsible for enlargement, said on one of his visits to Ankara that the Kurdish issue would 
be a crucial part of the Accession Partnership Document that was being prepared to delineate the necessary steps for Turkey's admission into the EU. ${ }^{12}$

Early indications of Turkey's response to Ocalan's politicization attempt began in January 2000, when the Turkish High Broadcasting Authority shut down CNN-Turk, a 24-hour news channel, for one day owing to an anchorman's questioning a guest on whether Ocalan would become 'the next Mandela'. Only a few days later, the Turkish State Security courts revealed their decision about the leadership of the main legal Kurdish party (HADEP), sentencing 16 leading figures to three years and nine months imprisonment on the basis of charges that they had helped and followed orders from the PKK. ${ }^{13}$ The state's response became still clearer in a statement in mid-March from a member of the National Security Council, declaring that Turkey was unlikely in the near future to allow either education or broadcasting in Kurdish, on the grounds that these would 'tear apart the mosaic' of Turkey's multi-ethnic society. ${ }^{14}$ Then President Demirel echoed this sentiment a few days later when he said, 'if we give Kurds free broadcasting and educational rights we will fall to pieces'. ${ }^{15}$

Another of the Turkish state's responses to what is viewed as evidence of the PKK's politicization attempt was the detention of three Kurdish HADEP mayors on charges of supporting the PKK. These detentions, coming on the heels of the mayors' meetings with European officials, were heavily criticized in Europe. Demirel responded that this was a criminal court case and therefore an internal Turkish matter ${ }^{16}$ though the leader of the coalition party ANAP, Mesut Yilmaz, admitted that the government leadership was caught unaware, implying that the security establishment had acted on its own. ${ }^{17}$ The HADEP mayors were released after three days and reinstated in office, though their trials continue. Their quick reinstatement in office was partly due to apparently increasing European pressure; however, it also suggests that their arrests and detentions were less a matter of law enforcement than one of the Turkish state sending a message to the PKK, to Europeans supportive of the PKK's new strategy, and to other HADEP mayors and Kurdish political figures.

With these arrests, the Turkish state establishment made a move against further politicization of the Kurdish issue and sent a warning to HADEP to cut its links with the PKK and to resist seeking alliances in Europe. Turkey also reminded Europe that it still sees the Kurdish issue as an internal problem, even if EU membership is on the table. A former Turkish army officer and politician was reported as saying that, by dealing with HADEP and the Kurdish issue, the EU is 'on the wrong path'.18

Such an assessment was arguably not unfounded, since Ocalan's political proposals have been largely unable to reach any audience except a European one. Only now do his political demands seem to be reaching Turkish officials via Turkey's attempts to accede to the European Union. In fact, Europe's demands for minority rights in the Accession Partnership Document have served 
to delineate more clearly the domestic fault lines between influential state actors in Turkey. Those parties in favor of a political response, holding tight to the justification of entering the European Union, have declared that recognizing some Kurdish rights is a 'must'19 or at least something to be considered. ${ }^{20}$ The army-led anti-political-response front, on the other hand, has not backed down from its negative position, though it tries to not appear completely opposed to EU accession, which has the overall support of most Turkish people. The army has nevertheless declared on several occasions that it is against the recognition of Kurdish cultural rights. Its strongest ally has appeared to be the Nationalist Action Party (MHP), whose leader has expressed his clear opposition to particular Kurdish rights, saying that this would lead to further separatist tendencies and conflictual developments. ${ }^{21}$ The Speaker of the Parliament, also an MHP member, has said that the demands for Kurdish rights in the Accession Partnership Document were more damaging than the Sèvres Agreement, which sought to divide Ottoman lands in the 1920s. ${ }^{22}$ Yet another MHP politician revealed the bottom line of his party's stance on the issue when he announced that they were against it 'all the way', because they could not allow the use of state resources to 'artificially create a language and a nation'.$^{23}$

A surprise ally for those in favor of a political response appeared as the director of the National Intelligence Organization announced that Kurdish television and education might in fact help the state to better manage problems in Turkey's southeast, since more than half of all Kurdish mothers in the region do not speak Turkish. He further implied that the army had a similar understanding. ${ }^{24}$ In the next National Security Council meeting, however, the army generals stipulated clearly that the army did 'not share the thoughts of the intelligence director' and added that such rights would be against the unitary character of the Turkish state. At the same time, a former navy commander stated publicly that Kurdish television broadcasting would not create a problem for Turkey. ${ }^{25}$ The Supreme Court Chief Justice also declared that 'some amount of Kurdish television' could be allowed, ${ }^{26}$ and the Foreign Ministry, under the leadership of Ismail Cem, ${ }^{27}$ continued its general support for Kurdish rights. The hardliner front gained the perhaps unexpected support at this time of the Turkish High Education Council, which issued a statement saying it opposed Kurdish television and education for similar reasons to those outlined earlier by the army. Clearly, at this stage, the Turkish state and government apparatus appeared very torn on the issue. ${ }^{28}$

Feeling surrounded and pressured to a degree rarely experienced in Turkish politics, the army opted to reiterate its stance on the Kurdish issue, but this time at a very sensitive juncture. At the exact moment when Turkish Prime Minister Ecevit was attempting to show Turkey's complete will to be a full EU candidate member through his attendance at and participation in the EU Summit in Nice, Turkish news agencies released a report that had been passed 
to them by the Chief of Staff's General Secretary. In this report, 'Evaluation of Internal Security Operations in 2000', the army clearly labels Kurdish television and education demands as the 'second dimension of separatist terrorism' and the 'revival and restructuring of the separatist movement through political means' ${ }^{29}$ After stranding the prime minister in this difficult position while abroad, the army refused to let up. Chief of Staff Kivrikoglu then visited Ecevit the following week, just prior to the coalition leaders' summit to design the outlines of Turkey's national program for EU accession, and again clearly indicated the army's opposition to Kurdish cultural rights and to the political strategies of the separatist movement. After this visit, Ecevit, though avoiding direct mention of his ideas on Kurdish television and broadcasting, seemed to show his agreement with the army's position that the PKK's politicization process constituted a genuine security concern for Turkey, particularly in light of the support being given to the process by the Europeans. ${ }^{30}$ At the subsequent leaders' summit, no decision on the issue was taken.

Volkan Vural, director of the newly established EU General Secretariat in Ankara, added his voice by pointing out that cultural rights are a clear and undisputed EU demand. Nevertheless, at the 22 December National Security Council meeting, the army once again argued that Kurdish cultural rights are a tactic of separatist terrorism, making it clear that Turkey will not respond to such demands in the national program - at least not in the near future. ${ }^{31}$ The hardliners appear to have won this brief and unusual struggle within the Turkish state structure; Turkey appears unprepared to respond to any type of political representation of Kurdish politics.

\section{Understanding Turkey's Emerging Response}

Another modern characterization of the national security syndrome outlined earlier is the country's enormous sensitivity about national unity. This sensitivity is continuously fed by the fear of being divided, which, as mentioned in note 5, has sometimes been labeled as Turkey's 'Sèvres Syndrome'. This fear is very deeply rooted both among public officials and in the society at large; therefore, any argument or movement which carries a separatist potential is readily seen as dangerous and subversive. Governmental and societal reflexes are quick to react against divisive threats. The four following reflections of the previously identified national security syndrome must be considered as the major factors supporting Turkey's emerging tough stance against the PKK's recent political moves. 


\section{Fears of Politicization and the IRA/Sinn Fein Model}

Notwithstanding Ocalan's and the PKK's pronouncements, the Turkish state establishment remains convinced that the PKK exists to divide Turkey. On 3 February 2000, the Secretary General of the National Security Council spoke of the 'PKK's true goal of carving out a separate state', ${ }^{32}$ and Prime Minister Ecevit was quoted as saying that the PKK's politicization attempts are the real danger Turkey faces - implying that the PKK's tactics may have changed, but the goals remain the same. ${ }^{33}$ Some PKK statements may be contributing to this fear. PKK central committee member Murat Karayilan said at the end of March 1999 that not only the language and culture but also Kurdish politics will be distinct, ${ }^{34}$ presumably implying the need for Kurdish-based political representation. Abdullah Ocalan's brother, Osman Ocalan, was also reported in intelligence report excerpts as saying that Kurdish television and education were seen as a way to a more integrated Kurdish nation, the mobilizing power for the future independent state. ${ }^{35}$ This emphasis on political rights not only undercuts Ocalan's promises of dropping political autonomy arguments, but also further provokes doubts about the sincerity of the PKK's new, ostensibly more limited goals. These doubts are deepened by reports of the PKK's arming and training four to five thousand men to use as a bargaining chip in their struggle for political recognition. The PKK's policies of withdrawing from Turkey but failing to give up their weaponry may suggest to the Turkish state the possible emergence of a future IRA/Sinn Fein structure - an armed wing being used by the political leadership in order to force their terms. Some Turkish career security officials claim that apparent splinter groups that have continued to fight despite Ocalan's importuning are not actually acting outside of PKK control. These groups are therefore considered by the Turkish establishment as part of the PKK's bargaining strategies. ${ }^{36}$

The Turkish security bureaucracy seems convinced that Turkey is facing the challenge of a process of increasing political recognition of the Kurdish separatist movement, which is basically the 'second period' of the separatist terror they have been fighting against. They believe that the PKK, having failed to gain political recognition and popularity through its military struggle, now hopes to gain it through 'innocent'-looking political strategies, such as adding power to Turkey's southeast municipal administrations where the Kurdish party HADEP is already in control and establishing cultural rights to Kurdish education and television broadcasting, which it is assumed would reduce the problematic impacts of Kurdish society's heterogeneity. The army clearly sees these efforts as part of a political war being waged by the PKK and defines them as attempts to develop a political separatist movement based on ethnic nationalism..$^{37}$ This is clearly seen as detrimental to national security, as was the PKK's earlier strategy of armed conflict. 
Thus, according to the Turkish armed forces, the terror and security threat is not yet over, but has merely entered a new phase. In this phase, the military is determined to do 'everything necessary to eradicate this new type of threat', and has stated that the 'struggle will last until the last terrorist is eliminated' ${ }^{38}$ The army's understanding is that the fight should continue until the end, because the 'PKK is determined to use its armed constituents as an umbrella for its efforts to get political recognition' and, 'unfortunately, some foreign and domestic circles are falling into this trap'.$^{39}$

In the political sphere, there seems to be increasing acceptance of the army's stance, with the MHP's support and recently even the prime minister's declaration of sharing the military's concerns about the politicization process and about European support of the PKK..$^{40}$ The army's unyielding positioning and its determining weight in Turkish domestic politics - particularly vis-à-vis national security affairs - is a clear indication that the struggle between Turkey and the PKK will continue within new parameters.

\section{The Economic Diagnosis}

The second major factor which eases Turkey's dismissal of any political or culture-based arguments is the traditional understanding that the southeastern or Kurdish question is primarily a problem based on economic issues or poverty. In this widely popular view, eliminating poverty would eliminate the PKK, since the PKK's fighting ranks are peopled strictly by those with no economic alternatives. Prime Minister Ecevit has been a traditional supporter of this view and has proposed the continuation of the current security-based regional governorship for the purpose of dealing with 'economic and social' factors. ${ }^{41}$ Chief of Staff Huseyin Kivrikoglu also proposed the establishment of an undersecretariat responsible for addressing economic problems in the region. ${ }^{42}$ Finally, former Turkish ambassador to the USA and much-consulted 'wiseman' to the Turkish state establishment Sukru Elekdag also pointed out that an 'economic master plan' for the southeast region was urgently needed in order to 'change the nature of the region which produces the human material for terror'. ${ }^{43}$ Supporting this interpretation is the observation that the nearly $60 \%$ of Kurds who live outside Turkey's southeast region are very much integrated into the socioeconomic structure of Turkey and are not, by and large, strong supporters of the PKK.

Accordingly, a new 'master action plan' has been put into effect. This plan was designed by the National Security Council Secretariat, upon the Council's recommendation to the government, and came into force with Prime Minster Ecevit's signature on 7 May 2000. Even though the details of the plan were never shared with the public, it is known to consist of 107 items for the improvement of economic conditions in Turkey's southeast region, such as promoting public education and health services. ${ }^{44}$ The limited role of civilians and 
the political sphere during the preparation and implementation of the plan has created doubts among some over whether it was fully supported by every political party in the coalition government. ${ }^{45} \mathrm{~A}$ major part of the infrastructural restructuring in the former conflict region of Turkey has been carried out under the de facto supervision of the armed forces. It has been reported that military troops are rebuilding bridges, schools and even villages, and that the civilian authorities are trying to provide 'logistical' support to them. ${ }^{46}$ The army even plays Ricky Martin music for the local youth, and in most ways seems to be playing the primary role in the region's redevelopment. Ultimately, these developments and the lack of political input into the process feed into the larger understanding that only an economic diagnosis of the problem is accurate and that economic investment should be the prescription. ${ }^{47}$

Of course, there are challenges to an economic understanding and to economic endeavors. First, it is far from proven theoretically that economic developments will silence the political/cultural demands of the emerging Kurdish politics. The unreliability of an economic solution is even greater in the wake of such a long and confrontational experience, which may very well have increased ethnic and political awareness among the Kurds. Second, several economic packages have emerged in the past out of this understanding and have sought to address the problems in the southeast. None of these were fully implemented, and so it remains unclear whether they would have had the intended results. Moreover, the economic crisis of early 2001, the worst in Turkish history, has left the country with minimized capacities to launch and implement new radical economic packages - not only in the southeast but over the entire country - a limitation that will not soon disappear.

\section{Mistrust in European Objectives}

The third factor at play here is Turkey's traditional mistrust of European objectives in the Kurdish issue. This mistrust continues in spite of Turkey's improved chances for EU membership and has been further strengthened by the European rush to reach out to HADEP as the party seen to be carrying out Ocalan's 'democratic struggle' strategy. An understanding may be gaining strength in Turkey that Europe is using the EU membership 'carrot' in order to facilitate political solutions to the Kurdish issue. Some analyses have appeared that suggest that the road map for full European Union membership might in fact be a road map for a political solution to the Kurdish question. Providing evidence for these concerns, Professor Bakir Caglar, a former judge in the European Court of Human Rights, has pointed out specific references within European Union documents to a 'civilian solution' to the southeast question, to the protection of 'minority rights', and to the 'protection of minority languages', in particular Kurdish. ${ }^{48}$ 
This identification of the politicization of the Kurdish question with full membership in the EU was further consolidated in people's minds after a much-quoted speech in which coalition leader Mesut Yilmaz stated that 'the road to the EU goes through Diyarbakir' ${ }^{49}$ the largest city at the center of the Kurdish-majority region of Turkey. Former Turkish foreign minister Mumtaz Soysal also captured this concern with his reference to the 'EU's Kurdish card'. ${ }^{50}$ The perception of EU manipulation of the Kurdish issue increased once the clearly detailed conditions of full EU membership were made public.

While there were several other points among the European demands within the Accession Partnership Document, the ones about the Kurdish issue grabbed the lion's share of the attention. Turkish hardliners in particular saw a parallel between the existing PKK demands and the European requests. On 1 December 2000, the Turkish army released a report emphasizing this overlap and named several European countries as supporters of the PKK's politicization tactics. This report implies that Europe can be considered a major part of an international conspiracy against Turkish unity. ${ }^{51}$ This report cannot easily be seen as an isolated perception or understanding, since a large portion of Turkish public opinion seems inclined to share these concerns. On 3 December 2000, for example, nearly every major newspaper allocated its headlines to an incident that took place within the European Union bureaucracy. It was reported that the Chief of the Turkish Desk in the EU sent an official letter to the PKK Central Committee and later claimed it was done by mistake..$^{52}$ Many Turkish journalists and members of the general public seemed to view this as the long-awaited evidence of an EU-PKK link. ${ }^{53}$ In the following days, Prime Minister Ecevit's statements were released confirming Turkey's mistrust of the European agenda and its suspicions of European support for the PKK and its strategies, while Deputy Prime Minister Bahceli stated that he did not find Europe 'sincere' vis-à-vis the Kurdish issue. ${ }^{54}$

The EU accession process may already be poisoned by the Kurdish issue and its European link. Turkey's perceptions and concerns about the PKK's new political strategies seem to be taking the upper hand and superceding even the EU integration issue itself.

\section{The Dilemma of Kurdish Politics}

A fourth reason behind the Turkish state's positioning could stem from the extreme problems legal Kurdish political movements in Turkey face in divorcing themselves from the PKK, thereby making it difficult for Turkey to find a fully non-PKK partner for dialogue. ${ }^{55}$ Politicians who attempt to appeal to Kurdish votes in the southeastern cities are partly dependent on constituents who are PKK sympathizers, since this group is more assertive and organized than the group's opponents. This is true not only for Kurdish parties like HADEP, but also for Kurdish deputies from other parties. Some Kurdish members of the 
Islamist Virtue Party have renounced their party membership, citing the party's tough stance on Ocalan's execution. This suggests that the PKK's concerns are becoming a significant part of Kurdish politics, further complicating the state's ability to recognize an acceptable political movement with Kurdish representation in it.

It seems as if the pro-Kurdish party HADEP's efforts to become a normal political party rather than one perceived as being controlled by pro-PKK elements remain primarily rhetorical. In their November 2000 convention, for example, the party administration was touted as having been renewed to include former members of other Turkish parties, such as Anavatan Partisi (ANAP) and Refah Partisi (RP), and stump speeches emphasized HADEP's lack of a separatist agenda. Nevertheless, actions on the convention floor such as protesting the Turkish flag, preventing the Turkish national anthem from being played, and, in particular, electing a chairman against whom there are outstanding charges of having aided the PKK - are perceived by much of the Turkish population as indicating continued PKK influence over the party, and therefore unreliability. ${ }^{56}$ Prime Minister Ecevit also referred to the convention crowd's behavior as evidence of a continuing PKK threat. ${ }^{57}$ Obviously, the dilemma that non-PKK-involved Kurdish policies seem unable to emerge strongly in Turkey forces the Turkish state and the political elite to opt for a general rejectionist behavior towards any type of Kurdish political representation, and this has obviously complicated the incorporation of ethnically conscious Kurdish political representation into the Turkish political space.

\section{Implications}

It is possible then to speak of a new impasse and a resurfacing of the 'imbroglio' surrounding Turkey's southeast/Kurdish question. Turkey is having difficulties in designing post-terror policies and is therefore resorting to the traditional economic understanding of the issue. On the other side, the PKK seems unprepared and unwilling to fully disarm and surrender, even though it seems now impossible to defeat the Turkish army. The only route remaining is one of political struggle, and this is the new format of the war between Turkey and the PKK.

The PKK's inevitable resorting to political and diplomatic means to reach its goals and the subsequent increasingly strong perception on the Turkish side that this constitutes a 'second phase' of Kurdish separatist terrorism clearly mean that the conflict between the parties is far from over. While European involvement in the Kurdish issue is also inevitable owing to the Europeanization of the Kurdish issue via the Kurdish diaspora, this serves as a constant provocation to Turkish suspicions that Europe seeks a divided Turkey. In 
addition, the domestic dominance of a traditional economic diagnosis and prescription for the Kurdish issue in Turkey leads to an environment of avoidance and diversion in which the other dimensions of the issue become overshadowed. ${ }^{58}$ Finally, the difficulties of creating a non-PKK-dominated Kurdish political representation further strengthens Turkish hardliners' position that the separatist terror is not over and that the state must remain on constant alert.

Three major implications might emerge out of this environment. First, this may signal a return to combat with different patterns, but without the elimination of violence, along the lines of the IRA/Sinn Fein structure. As long as the armed units of the PKK are used or perceived as bargaining/blackmailing elements, Turkey will feel forced to conduct operations - even cross-border ones - to eliminate these units. There is the possibility, therefore, that the conflict level in Turkey may rise again, leading to instability both at home and in the region owing to the transnational character of the issue.

The second implication of the new pattern of conflict may concern Turkey's foreign relations with the West. It is not a new phenomenon for Turkish foreign policymakers to be constrained by the international linkages of the Kurdish issue. Now that the political recognition of the Kurdish issue is becoming the main emphasis of Kurdish elements, particularly those within the Kurdish diaspora, Turkey is likely to face mounting pressure over the issue. In the past, the PKK's terrorist activities made it relatively easy for Turkey to condemn and dismiss international interest in the issue. Now, however, the political recognition of an organization presenting itself as acting on behalf of minority rights based on standard rights recognized in the West will make it difficult for Turkey to easily defend its positioning. Even countries outside the region may have interests in the political recognition of the PKK and Turkey's Kurdish issue. The problem for Turkey's foreign policy towards the West, therefore, is the emerging divide between the latter's interpretation of minority rights and Turkey's political organizational principles on this issue.

The third possible implication embraces the structure of Turkish domestic politics. The civilian political forces have so far been unable to take the initiative and tackle the post-terror era of the southeast question with plans for addressing the social, economic, and cultural needs of southeast Turkey. Since the failure to adequately challenge the PKK's new moves continues, the Turkish security establishment, which is designed to defeat the PKK under combat conditions, is certain to continue to take action. A continuing larger role for the army vis-à-vis this issue may keep the country's political structure unbalanced in terms of civil-military relations - already a concern for the EU accession process. In combating the new political nature of this problem, it is the political elite and civilian bureaucrats who must be at the forefront of the struggle. At the same time, mistrust of European intentions will complicate any formulation of civilian-led strategies, especially on the issue of Kurdish 
political rights. This may in turn poison possible major progress in TurkishEU relations.

This article has shown that there are structural limits to Turkey's ability to address the Kurdish issue in a manner acceptable to the Europeans. The Europeans should, therefore, pay greater attention to Turkey's national security syndrome, which is the hub of these limits. Addressing the needs of Turkey's security perceptions directly and, perhaps more importantly, providing security assurances to Turkey will perhaps help Turks overcome their national security syndrome and lead to more satisfying developments in terms of both the Kurdish issue and Turkish-EU relations.

\section{NOTES AND REFERENCES}

* Ersel Aydinli is an Instructor in the Department of International Relations at Bilkent University and a Senior Researcher at the Center for Eurasian Strategic Studies (ASAM) in Ankara, Turkey. The author can be reached at aydinli@bilkent.edu.tr. The author would like to thank the referees and editor for their helpful suggestions.

1 This major pattern in the Turkish state agenda has been almost unanimously identified and agreed upon by most of the leading works on the issue. See, for example, Kemal Kirisci \& Gareth Winrow, The Kurdish Question and Turkey: An Example of a Trans-State Ethnic Conflict (London: Frank Cass, 1997); Henri J. Barkey \& Graham E. Fuller, Turkey's Kurdish Question (Lanham, MD: Rowman \& Littlefield, 1998); Nicole Pope \& Hugh Pope, Turkey Unveiled: A History of Modern Turkey (Woodstock: Overlook Press, 1998); David McDowall, A Modern History of the Kurds (London: I.B. Tauris, 1996); Ismet G. Imset, 'The PKK: A Report on Separatist Violence in Turkey' (Istanbul: Turkish Daily News Publication, 1992)

2 Even recent works do not fully analyze this structural aspect of the issue. See, for example, Michael Gunter, 'The Continuing Kurdish Problem in Turkey after Ocalan's Capture', Third World Quarterly, vol. 21, no. 5, October 2000, pp. 849-869.

3 During the Ottoman modernization periods, it can be proposed that the bureaucrats were able to force great changes on the Sultans - such as power-sharing or even a constitutional monarchy - by arguing that the Sultans were failing to provide adequate security. In this sense, power relocation was forced upon the system to ensure that stronger figures handled security issues.

4 One of the most obvious examples of this occurred when the increasingly powerful modernizing Ottoman bureaucracy dismissed Sultan Abdulaziz and replaced him with Murat $\mathrm{V}$, with the ostensible intention of initiating a constitutional monarchy. The following dialogue was recorded between Suleyman Pasha and the then prime minister: 'If we are not going to declare the constitutional reform, why did we overthrow the Sultan ... just to get a new one?' 'The state trusts you [bureaucrats]. Would you rather go ask the ignorant Turks of Anatolia about the destiny and security of our state?'; Tevfik Cavdar, Turkiye'nin Demokrasi Tarihi 1839-1950 [The History of Turkish Democracy 1839-1950] (Ankara: Imge-Ankara Kitabevi, 1999). 
5 One significant understanding of the concept of national security has been the idea of national unity, or keeping the country from being divided. Turkish fears of being divided have often been referred to as 'the Sèvres Syndrome', referring to the 1920 Sèvres agreement that officially ended the Ottoman Empire and divided the Anatolian lands, creating an Armenian state and a Kurdish autonomous region with the possibility of independence in the future. The Turkish Independence War halted and made void the agreement. Nevertheless, since the Sèvres agreement was imposed by Western powers, its goal to divide the country continues to weigh heavily in the common memories of the Turkish state and society.

6 Then prime minister Fethi Okyar is reported as having said, 'I will not shed blood unnecessarily', TBMM Tutanaklari, Parliamentary archives, v. 2, s. 13, 1924.

7 The new government, led by hawkish Ismet Inonu, introduced an emergency law called 'Takrir-i Sukun' (Reconstruction of the Order), which gave every authority to the state in order to curb anything it considered dangerous to its internal stability. The tribunals took advantage of this new law and shut down the party.

8 Recorded in the memoirs of Free Party leader Ahmet Agaoglu, Serbest Firka Hatiralari [Free Party Memoirs] (Istanbul: Baha Matbasi, 1969, p. 63-64).

9 The rebellion took place in a small town in Western Anatolia, where the support for the Free Party was highly visible.

10 PKK Presidential Council member Mustafa Karasu stated that the PKK would keep its armed forces intact and ready until the 'democratic conditions' in Turkey were ready for them to return (Ozgur Politika, 28 March 2000), while the PKK Presidential Council declared that the threat potential of these armed groups could be altered only 'if Turkey abolishes the death penalty, declares general amnesty and expands liberties' as preliminary concessions (Ozgur Politika, 28 March 2000). Finally, another Council member and brother of Abdullah Ocalan, Osman Ocalan, noted that these forces are trained for 'political motives' in order to adapt to a projected 'democratic expansion' in Turkey (Ozgur Politika, 12 March 2000).

11 The figure of 300 and related information were reported in Ozgur Politika in reference to a police report submitted to the Turkish National Security Council, 27 February 2000.

12 Milliyet, 22 March 2000.

13 Turkish Daily News, Milliyet, Hurriyet, Sabah, 18 January 2000.

14 Financial Times, 17 February 2000.

15 Turkish Daily News, 22 February 2000.

16 Sabah, Milliyet, 23 February 2000 and New York Times, 25 February 2000.

17 NTV - Turkiye'den Haberler, 25 February 2000.

18 Orhan Kilercioglu, quoted in the Turkish Daily News, 25 February 2000.

19 Deputy Prime Minister Yilmaz, who is in charge of Turkey's accession to the EU, stated that Kurdish television and education was not only necessary for entering the EU but was also a domestic need to be met. Sabah, 8 December 2000.

20 Prime Minister Ecevit also revealed his positive attitude towards the Kurdish education issue (Milliyet, 6 December 2000), while President Sezer is reported as saying that Turkey should take whatever steps necessary to bring it closer to the EU - a statement 
that can be interpreted as a positive stance towards the Kurdish television and education issue. Radikal, 9 December 2000.

21 Devlet Bahceli, reported in Milliyet, 15 October 2000.

22 See note 5 (above).

23 Omer Izgi, reported in Hurriyet, 14 October 2000.

24 NTV Television News, 21 December 2000.

25 Salim Dervisoglu reported in Sabah, 1 December 2000.

26 Mustafa Bumin reported in Cumhurriyet, 1 December 2000.

27 Sedat Ergin, 'Disisleri ve Kurtce TV' [The Foreign Ministry and Kurdish Television], Hurriyet, 2 December 2000.

28 Mesut Yilmaz was reported as saying that there was 'no harmony' within the state on this issue; Sabah, 12 December 2000. For a detailed analysis of the fault lines in Turkish domestic politics on this issue, see Ersel Aydinli \& Dov Waxman, 'A Dream Become Nightmare: Turkey's Entry into the European Union', Current History, vol. 100, no. 649, November 2001, pp. 381-388.

29 Milliyet, 8 December 2000.

30 Radikal, 12 December 2000.

31 'NSC: No to Kurdish Television', Turkish Daily News, 24 December 2000.

32 Cumhur Asparuk as cited in Financial Times, 17 February 2000.

33 'PKK siyasallasamaz' [The PKK Must Not Be Politicized], Sabah, 17 January 2000.

34 Ozgur Politika, 28 March 1999.

35 Yavuz Donat, Sabah, 12 December 2000.

36 These views were revealed in private interviews held in summer 1999 and spring 2000 between the author and several Turkish security officials, names withheld upon request.

37 Ibid.

38 From the annual report on internal security, Hurriyet, 8 December 2000.

39 Ibid.

40 Sabah, 12 December 2000.

41 Bulent Ecevit, reported in Hurriyet, 16 January 2000.

42 This suggestion was reportedly made at the end of 1999, and is referred to in Dogan Heper's column entitled 'PKK bitti, simdi yatirim zamani' [The PKK Is Finished Off, This Is the Time for Investments], Milliyet, 17 February 2000.

43 Sukru Elekdag, Milliyet, 21 February 2000.

44 Sedat Ergin, 'Guneydogu icin hukumetten beklenen' [What Is Expected from the Government for the Southeast], Hurriyet, 22 September 2000.

45 Ergin raises doubts that the ANAP (Motherland) and MHP have demonstrated their clear commitment to the plan. Ibid.

46 Ali Bayramoglu, Yenibinyil, 19 August 1999.

47 Most media references to the salvaging of the southeast Kurdish problem remain based on economic premises. Necati Dogru talks about the existence of local governors with MBA degrees and the difference this can make, as opposed to the previous governors with 'sticks in their hands'. Sabah, 24 December 2000. Dogan Heper seems confident that a magical number of ' 42 ' businessmen - two per province - can save the region and solve its problems. Milliyet, 21 September 2000. 
48 For details, titles, and dates of the documents on these elements, see 'Entellektuel Bakis', an interview with Bakir Caglar, Milliyet, 26 February 2000.

49 Milliyet, Sabah, 19 November 1999.

50 Mumtaz Soysal, 'AB'nin Kurt Karti' [The EU's Kurdish Card], Hurriyet, 1 March 2000.

51 The report names Sweden, Finland, the Netherlands, Belgium, Greece, Germany, and France as making the same demands as the PKK. Cumhuriyet, 1 December 2000.

52 The bureaucrat, Alain Servantie, later apologized, saying it had been a secretarial mistake; all major Turkish daily newspapers, 3 December 2000.

53 Openly skeptical columnists used this opportunity to once again criticize the EU. Emin Colasan referred to this as an opportunity to see the true face of Europe. He also called the Turkish EU adventure a 'dangerous dream'. 'Bir Rezalet Daha' [One More Scandal], Milliyet, 3 December 2000.

54 Sabah, 8 December 2000, and Hurriyet, 10 December 2000.

55 It should be noted that some attempts to create non-PKK-influenced Kurdish political movements have suffered from the failure of the latter to emerge as influential powers. Others movements have not been considered as viable dialogue partners because they have employed a rhetoric equally or even more radical than that of the PKK itself.

56 See, for example, Taha Akyol, who in his column wrote, 'how can we trust HADEP if they don't pay respect to the common values of this nation?'; 'HADEP Yanlista' [HADEP Is in the Wrong], Milliyet, 28 November 2000.

57 Yenisafak, 30 November 2000.

58 Whether or not the primacy of an economic diagnosis can prevail remains unclear, since the currently prescribed 'master plan' to develop Turkey's southeast region is in fact the eleventh such plan, the previous ten of which have all been labeled as failures. There are indications already that this plan will also have problems, for example, the CEO of 'East Holding' (created for this plan) resigned in early 2001, claiming that the plan lacked the full backing of the state and private sectors; Radikal, 6 January 2001. 